\title{
Silencing Acid-Sensing Ion Channel 1a Alters Cone-Mediated Retinal Function
}

\author{
Mohammed Ettaiche, Emmanuel Deval, Marc Cougnon, Michel Lazdunski, and Nicolas Voilley \\ Institut de Pharmacologie Moléculaire et Cellulaire, Centre National de la Recherche Scientifique, Unité Mixte de Recherche 6097, Universtité de Nice- \\ Sophia Antipolis, Institut Paul Hamel, Sophia Antipolis, 06560 Valbonne, France
}

The action of extracellular protons on retinal activity and phototransduction occurs through pH-sensitive elements, mainly membrane conductances present on the different cell types of the outer and inner nuclear layers and of the ganglion cell layer. Acid-sensing ion channels (ASICs) are depolarizing conductances that are directly activated by protons. We investigated the participation of ASIC1a, a particular isoform of ASICs, in retinal physiology in vivo using electroretinogram measurements. In situ hybridization and immunohistochemistry localized ASIC1a in the outer and inner nuclear layers (cone photoreceptors, horizontal cells, some amacrine and bipolar cells) and in the ganglion cell layer. Both the in vivo knockdown of ASICla by antisense oligonucleotides and the in vivo blocking of its activity by PcTx 1, a specific venom peptide, were able to decrease significantly and reversibly the photopic a- and b-waves and oscillatory potentials. Our study indicates that ASICla is an important channel in normal retinal activity. Being present in the inner segments of cones and inner nuclear layer cells, and mainly at synaptic cleft levels, it could participate in gain adaptation to ambient light of the cone pathway, facilitating cone hyperpolarization in brightness and modulating synaptic transmission of the light-induced visual signal.

Key words: acid-sensing ion channel; retina; ASICla; cone photoreceptor; $\mathrm{pH}$; proton-gated current

\section{Introduction}

In vertebrates, the retina is submitted to physiopathological changes in extracellular $\mathrm{pH}$ that influence its activity. A pH gradient exists through normal retina that follows a circadian rhythm (Dmitriev and Mangel, 2001) and that is shifted by light (Borgula et al., 1989; Yamamoto et al., 1992). Acidic transients are thought to be involved in the fine tuning of visual perception and to play a role in the adaptation to ambient light intensities (Oakley and Wen, 1989; Donner et al., 1990; Newman, 1996). Photoreceptors extrude the acid produced by their high metabolic activity (Winkler, 1981) and, in dark conditions, continuously release glutamate toward the inner nuclear layer (INL) cells (Ayoub et al., 1989; Copenhagen and Jahr, 1989), which vesicle content is acidic and acidifies the synaptic clefts (Krishtal et al., 1987; Miesenbock et al., 1998; Palmer et al., 2003). Muller cells also participate in extracellular $\mathrm{pH}$ regulation (Oakley and Wen, 1989; Donner et al., 1990; Newman, 1996), and the pigment epithelium extrudes proton on its apical side (Zadunaisky et al., 1989).

The action of extracellular protons on retinal activity and pho-

Received Aug. 10, 2005; revised April 3, 2006; accepted April 3, 2006.

This work was supported by the Centre National de la Recherche Scientifique, the Fondation pour la Recherche Médicale, and the Fondation Paul Hamel. We are grateful to Drs. Pierre Escoubas for the generous gift of recombinant PcTx1, Lachlan Rash for ${ }^{125}$ I-PcTx1, Rainer Waldmann for anti-ASIC1a antibodies, and Sylvie Diochot and Anne Baron for fruitful discussion.

Correspondence should be addressed to Prof. Michel Lazdunski, Institut de Pharmacologie Moléculaire et Cellulaire, Centre National de la Recherche Scientifique, Unité Mixte de Recherche 6097, Universtité de Nice-Sophia Antipolis, Institut Paul Hamel, 660 route des Lucioles, Sophia Antipolis, 06560 Valbonne, France. E-mail: ipmc@ipmc.cnrs.fr.

DOI:10.1523/JNEUROSCI.0344-06.2006

Copyright $\odot 2006$ Society for Neuroscience $\quad$ 0270-6474/06/265800-10\$15.00/0 totransduction can be explained by $\mathrm{pH}$-sensitive membrane conductances in retinal neurons. Some ionotropic receptors and ion channels respond to $\mathrm{pH}$ changes: NMDA (Tang et al., 1990; Traynelis and Cull-Candy, 1990; Vyklicky et al., 1990) and GABA A $_{\text {A }}$ (Pasternack et al., 1996; Wegelius et al., 1996) receptors in the presence of their ligands and voltage-gated calcium channels (Iijima et al., 1986). Acid-sensing ion channels (ASICs) are depolarizing conductances that are directly activated by protons independently of any changes in membrane potential and any other known ligand. They activate under extracellular acidification in the physiopathological range (Waldmann et al., 1999; Krishtal, 2003). They have been implicated in pain perception and inflammation at the periphery, and in synaptic modulation in the CNS. Their expression and activity are induced by inflammation (Voilley et al., 2001; Mamet et al., 2002, 2003) and are directly inhibited by nonsteroid anti-inflammatory drugs (Voilley et al., 2001; Voilley, 2004). Functional ASICs are homomeric or heteromeric tetramers made of isoforms encoded by four different genes, two of them spliced in two variants: ASIC1a and ASIC1b, ASIC2a and ASIC2b, and ASIC3 and ASIC4 (Waldmann et al., 1996; Garcia-Anoveros et al., 1997; Lingueglia et al., 1997; Waldmann et al., 1997a,b; Chen et al., 1998; Akopian et al., 2000; Grunder et al., 2001). Their properties vary according to their subunit composition.

ASIC1a has been detected in the retina (Brockway et al., 2002), and its involvement in ganglion cell activity has been suggested (Lilley et al., 2004). We investigated here the in vivo effect of ASIC1a activity impairment in the retinal function by two different means: (1) direct blockage of homomeric ASIC1a channels by Psalmotoxin 1 (PcTx1), a toxin peptide that specifically blocks its activity, and (2) ASIC1a isoform knock-down using antisense 
oligonucleotides. Our results show that the silencing of ASIC1a expression and activity has a potent impact on retinal activity and particularly on cone function.

\section{Materials and Methods}

Animals. Adult (200-250 g) male Brown Norway rats (Charles River, Saint-Aubin les Elbeuf, France) were housed in plastic cages on a $12 \mathrm{~h}$ light/dark cycle [in fixed $50 \mathrm{~lx}$ fluorescent (Philips, Suresnes, France) lighting schedule with lights on from 8:00 A.M. to 8:00 P.M.] with ad libitum access to food and water. Litters were directly purchased (Charles River) and used at approximately postnatal day 9 (P9) to P11 for retina primary cultures. Rats were acclimated for 1 week before experiments. These studies were performed in accordance with the Association for Research in Vision and Ophthalmology Statement for the Use of Animals in Ophthalmic and Vision Research.

In situ hybridization, immunohistochemistry, and binding experiments. For in situ hybridization, adult Brown Norway rats were killed with a lethal dose of pentobarbital ( $240 \mathrm{mg} / \mathrm{kg}$, i.p.). Eyes were enucleated and eyecups fixed in $4 \%$ paraformaldehyde in PBS for $2 \mathrm{~h}$, washed in PBS before cryoprotection $\left(20 \%\right.$ sucrose for $1 \mathrm{~h}$ at $\left.4^{\circ} \mathrm{C}\right)$, and embedded in Tissue-Tek (OCT; Sakura Finetek, Leiden, The Netherlands). In situ hybridization was performed on $12 \mu \mathrm{m}$ sections as described previously (Voilley et al., 2001) using the GenPoint detection system (DakoCytomation, Trappes, France), and the following ASICla oligonucleotide probe was used: 5'-CATT-CTTG-GAGA-CTT-GGCT-AAA-GCGGAAC-3'. A sense oligonucleotide (5'-CACA-GATG-GCT-GAT-GAAAAGC-AG-3') was used as a negative control. Slides were mounted in DakoCytomation mounting medium. For immunochemistry and double labeling, frozen retinal sections were permeabilized with $0.1 \%$ Triton $\mathrm{X}-100$ in PBS for $30 \mathrm{~min}$, rinsed, and blocked with $10 \%$ goat serum in PBS to avoid nonspecific staining. ASICla was detected using a polyclonal anti-ASIC1a antibody (1:200) kindly provided by Dr. R. Waldmann (Institut de Pharmacologie Moleculaire et Cellulaire, Valbonne, France), incubated on sections overnight. Detection was done using a biotinylated secondary antibody (anti-rabbit, 1:100; Vector Laboratories, Burlingame, CA) and FITC-coupled streptavidin (1:80; DakoCytomation). In double-immunostaining experiments, cell type marker antibodies were incubated overnight at $4^{\circ} \mathrm{C}$ and detected with an indocarbocyanine (Cy-3)-labeled anti-mouse IgG (1:300; Invitrogen, Cergy Pontoise, France). Sections were stained without primary antibody as control. The specificity of the anti-ASICla antibody was checked in the retina by Western blot analysis. Total proteins were prepared from ASIC1a-transfected COS cells and rat retina. Proteins were separated by a 12\% SDS-PAGE and transferred to Immobilon (Millipore, Molsheim, France). Labeling was done using standard technique with ASIC1a primary antibody (1:200). Detection was done with a peroxidase-coupled anti-rabbit IgG (1:10,000; Amersham Biosciences, Les Ulis, France) and ECT substrate (Amersham Biosciences). Cones were localized with Alexa 594-conjugated peanut agglutinin (PNA) lectin (Invitrogen) at $2 \mu \mathrm{g} / \mathrm{ml}$, horizontal cells with anti-calbindin monoclonal D-28K antibody (1:1000; clone CB-955; Sigma-Aldrich, St. Quentin Fallavier, France), rod bipolar cells with anti-protein kinase $\mathrm{C} \alpha(\mathrm{PKC} \alpha)$ monoclonal antibody (1:800; clone MC5; Sigma-Aldrich), amacrine cells with anti-syntaxin monoclonal antibody (1:1000; clone HPC-1; Sigma-Aldrich), and ganglion cells with anti-Thyl.1 antibody (Thy1[MRC OX-7]; Abcam, Cambridge, UK). Slides were examined and photographed using an Axioplan2 Imaging microscope (Zeiss, Thornwood, NY).

Binding experiments were performed on adult Brown Norway rat retina membranes with ${ }^{125}$ I-PcTxl as in the study by Salinas et al. (2005). Membranes were prepared by sonicating retinas in lysis buffer $(20 \mathrm{~mm}$ HEPES, pH 7.0, 0.2 mм EDTA, protease inhibitor mixture; Roche Applied Science, Meylan, France). An amount of membrane corresponding to $100 \mu \mathrm{g}$ of total protein was incubated for $50 \mathrm{~min}$ with ${ }^{125} \mathrm{I}-\mathrm{PcTx} 1$ in binding buffer (in mM: $5 \mathrm{KCl}, 2 \mathrm{CaCl}_{2}, 2 \mathrm{MgCl}_{2}, 20 \mathrm{MES}$, pH 6.25, plus $0.1 \% \mathrm{BSA}$ ) and filtered on cellulose acetate $0.2 \mu \mathrm{m}$ pore filters (Sartorius, Goettingen, Germany). Filters were then washed twice with binding buffer plus $150 \mathrm{~mm} \mathrm{NaCl}$ and counted for $1 \mathrm{~min}$ (Multidetector Gamma System; Packard Instruments, Meridian, CT). Saturation data were analyzed and Scatchard plotted.
Cell culture, electrophysiology, reverse transcription-PCR, and antisense oligonucleotide characterization. Retina cell primary cultures were prepared from Brown Norway newborns. Retinas were removed and mechanically dissociated at room temperature in HBSS containing $10 \mathrm{U} / \mathrm{ml}$ papain, $0.2 \mathrm{mg} / \mathrm{ml} \mathrm{L}$-cysteine, $0.2 \mathrm{mg} / \mathrm{ml} \mathrm{BSA}$, and $0.5 \mathrm{mg} / \mathrm{ml}$ DNase I (all from Sigma-Aldrich). After a wash with HBSS, cells were passed through a nylon $40 \mu \mathrm{m}$ mesh and seeded at $10^{6}$ cells $/ \mathrm{ml}$ on poly-D-lysine-coated dishes (Biocoat; Becton Dickinson, Heidelberg, Germany) in DMEM (Invitrogen) supplemented with 5\% fetal bovine serum (ICN Biomedicals, Orsay, France) plus 5\% horse serum (Sigma-Aldrich) and kept at $37^{\circ} \mathrm{C}$ under $5 \% \mathrm{CO}_{2}$. For electrophysiological measurements on ganglion cells, anti-Thy1.1 antibody (Thy1 [MRC OX-7]; Abcam) was added on alive cells, carefully washed away, and detection used an anti-mouse $\mathrm{F}(\mathrm{ab})^{\prime} 2$ coupled to Alexa 594 as secondary antibody (Invitrogen).

The F-11 cell line (Platika et al., 1985; Francel et al., 1987) was grown in Ham's F-12 medium (Invitrogen) plus 15\% fetal bovine serum (ICN Biomedicals), supplemented with $1 \times$ HAT (sodium hypoxanthine, aminopterin, and thymidine), $200 \mu \mathrm{g} / \mathrm{ml}$ allo-4-hydroxy-L-proline (SigmaAldrich), and antibiotics at $37^{\circ} \mathrm{C}$ under $5 \% \mathrm{CO}_{2}$ at a density of $10^{5}$ cells per $35 \mathrm{~mm}$ diameter Petri dish.

Oligonucleotides were selected from two different sites of the rat ASIC1a mRNA (accession number U94403) according to stated principles, and for each antisense oligonucleotide, the inverted sequence oligonucleotide was used as control (Toulmé et al., 1997). They were synthesized as phosphorothioate derivatives with or without a $5^{\prime}$-fluorescein and HPLC-purified by the supplier (MWG-Biotech, High Point, NC). Oligonucleotides were cleaned by ethanol precipitation, resuspended at 2 $\mu \mathrm{g} / \mu \mathrm{l}$ in saline. The 16-mer AS1 was design to encompass the translation initiation site (5'-CA-ATT-CCA-TCC-TTG-CC-3'), and the inverted sequence IS1 was used as control ( $5^{\prime}$-CC-GTT-CCT-ACC-TTA-AC- $\left.3^{\prime}\right)$. The 18-mer AS2 was design in the $5^{\prime}$ part of the coding sequence (5'-GTGCC-CGC-TTC-AGA-GACA-3'), and the inverted sequence IS2 was used as control ( $5^{\prime}$-AC-AGA-GAC-TTC-GCCC-GTG-3').

F-11 cell transfection with oligonucleotides was done with Oligofectamine Reagent using the protocol of the supplier (Invitrogen), scaling up the given proportions for $35 \mathrm{~mm}$ Petri dishes to keep $200 \mathrm{~nm}$ oligonucleotide final concentration. Electrophysiological measurements were performed $1-3 \mathrm{~d}$ after plating for retina primary cultures and after 2-5 d for F-11 cells. We used the whole-cell configuration of the patchclamp technique (Hamill et al., 1981) to measure membrane currents. The pipette solution contained the following (in mM): $140 \mathrm{KCl}, 5 \mathrm{NaCl}, 2$ $\mathrm{MgCl}_{2}, 5$ EGTA, 10 HEPES, pH 7.25. The bath solution contained the following (in mM): $150 \mathrm{NaCl}, 5 \mathrm{KCl}, 2 \mathrm{MgCl}_{2}, 2 \mathrm{CaCl}_{2}, 10 \mathrm{HEPES}$, pH 7.4. MES was used instead of HEPES to buffer bath solution $\mathrm{pH}$ ranging from 6 to 5 . For retina primary cultures, the bath solution was supplemented with $10 \mathrm{~mm}$ glucose, and the pipette solution was modified as follows (in mM): $140 \mathrm{KCl}, 2.5 \mathrm{Na}_{2}$-ATP, $2 \mathrm{MgCl}_{2}, 2 \mathrm{CaCl}_{2}, 5$ EGTA, 10 HEPES, pH 7.25. Currents were amplified with an RK-400 amplifier (Bio-Logic, Claix, France), digitized with a 16-bit data acquisition system (Digidata 1322A; Molecular Devices, Union City, CA) and recorded on a hard disk using pClamp software (Clampex, version 8.2.0.224; Molecular Devices). Off-line analysis of the currents was performed using pClamp (Clampfit, version 9.0.1.21; Molecular Devices). Data were represented as means \pm SEM, and the statistical significance of differences between sets of data were estimated using the Student's $t$ test or the nonparametric one-way ANOVA (Kruskal-Wallis test followed by Dunns post hoc test; GraphPad Prism 4.0 software; GraphPad Software, San Diego, CA). Experiments were performed at room temperature $\left(20-22^{\circ} \mathrm{C}\right)$.

Total RNA from F-11 cells was prepared using the NucleoSpin RNA II kit (Macherey-Nagel, Duren, Germany). Reverse transcription (RT) and PCR were achieved as described previously using ASICla-specific primers (Voilley et al., 2001).

Antisense and PcTx1 treatments in vivo. Oligonucleotides (same as above) were prepared at $2 \mu \mathrm{g} / \mu \mathrm{l}$ in saline and the Psalmotoxin 1 (PcTx1) solution was prepared from recombinant PcTx1 (Escoubas et al., 2003). PcTx1 was dissolved in sterile water at $5 \mathrm{~mm}$ and diluted in buffer solution (in mM: $150 \mathrm{NaCl}, 2 \mathrm{CaCl}_{2}, 2 \mathrm{MgCl}_{2}, 5 \mathrm{KCl}$, and $10 \mathrm{HEPES}, \mathrm{pH} 7.4$ ). The estimated final vitreal concentration $(500 \mathrm{~nm})$ was calculated by assuming an average vitreous chamber volume of $30 \mu \mathrm{l}$. Intraocular in- 
jection was done under light general anesthesia (66.7 mg/kg ketamine, $11 \mathrm{mg} / \mathrm{kg}$ xylazine, i.p.) and local anesthesia in one eye of adult Brown Norway rats. The contralateral eye was injected with buffer or saline alone and served as control. Solution $(2.5 \mu \mathrm{l})$ was injected intravitreally at day 0 via a $30 \mathrm{G}$ needle (Microlance; Becton Dickinson) attached to a $10 \mu \mathrm{l}$ Hamilton syringe under an operating microscope. The needle was inserted through the sclera superiorly to $1 \mathrm{~mm}$ behind the nimbus at an angle of $45^{\circ}$ to avoid contact with the lens. For oligonucleotides, the first injection was realized in the superior part of the eye, and a second injection was done $2 \mathrm{~d}$ after in the inferior part. Animals with eyes that showed any experimental trauma (opacification of the lens or retinal hemorrhage) when checked with an ophthalmoscope were excluded.

Electroretinography. The rats were anesthetized $(66.7 \mathrm{mg} / \mathrm{kg}$ ketamine plus $11 \mathrm{mg} / \mathrm{kg}$ xylazine, i.p.) under dim red light $(640 \mathrm{~nm})$ and placed on a heating pad to maintain body temperature near $38^{\circ} \mathrm{C}$. Pupils were dilated with 2.5\% Neosynephrine and 0.5\% Mydriaticum, and corneas were kept moist with local application of $1 \%$ carboxymethylcellulose sodium (Celluvisc; Allergan, Irvine, CA). The conemediated responses [photopic electroretinogram (ERG)] were recorded with an ERG test system (UTAS 2000; LKC Technologies, Gaithersburg, MD) after the eyes were submitted to $10 \mathrm{~min}$ of $30 \mathrm{~cd} . \mathrm{m}^{-2}$ background light adaptation using a UV-filtered white light emitted by optic fibers connected to cold light sources (KL 2500 LCD; SCHOTT, Pont-sur-Yonne, France). Treated and control animals were submitted to measurements under identical states of anesthesia and adaptation, at day 0 before treatment and after $4 \mathrm{~h}, 1 \mathrm{~d}$, and $3 \mathrm{~d}$ after PcTx 1 injection or after 3, 5, and $7 \mathrm{~d}$ after the second injection of oligonucleotides. White bright light stimuli were produced by a Grass PS 22 xenonflash at $2.1 \mathrm{~Hz}$ (Peachey et al., 1993; Goto et al., 1995; Peachey et al., 1995) positioned $15 \mathrm{~cm}$ from the eye, ranging from $1.06-2.98 \log \mathrm{cd} . \mathrm{s.} \mathrm{m}^{-2}$ and presented, and 50 consecutive responses were averaged. The photopic signals were acquired at $2 \mathrm{kHz}$ with high- and low-pass filters set to 0.3 and $500 \mathrm{~Hz}$, respectively. Flash intensities were controlled with neutral density filters and calibrated with a radiometer-photometer IL 1700 (International Light, Newburyport, MA). ERG components were calculated with the electron microscopic (EM) software provided with the recording system. The amplitude of the a-wave was measured from the prestimulus baseline to the apex negative peak of the a-wave. The b-wave amplitude was measured from the a-wave negative peak to the b-wave positive peak (and not to the peak oscillations that can be higher than the apex). Oscillatory potentials (OPs), which are superimposed over the ascending phase of the ERG b-wave, were extracted for the highest and the lowest stimulus intensity using EM software with two filtering operations equivalent to applying a bandpass filter with corner frequencies of 73 and $500 \mathrm{~Hz}$. To examine the time course of the ERGs, the implicit times of the a- and b-waves were analyzed. They were calculated as the time between the onset of the stimulus and the peak of the response.

\section{Results}

\section{Localization of ASIC1a in the retina}

In situ hybridization was used to localize ASIC1 a mRNA in the rat retina. As shown in Figure 1, ASIC1a mRNA was present in cells of the outer nuclear layer, the inner nuclear layer, and in some ganglion and/or displaced amacrine cells. Labeled photorecep- tors of the outer nuclear layer could be cone cells, because the positive cells were scattered throughout the outer nuclear layer as a typical mosaic.

We also performed binding experiments of ${ }^{125} \mathrm{I}-\mathrm{PcT} \mathrm{T} 1$ on retina membranes. Characteristics of the binding showed a single site, a $B_{\max }$ value of $1.6 \mathrm{fmol} / \mathrm{mg}$ of total proteins and a $K_{\mathrm{d}}$ value of $25 \mathrm{pm}$ (Fig. $1 D$ ). This confirmed the presence of ASIC1a protein that could specifically bind to PcTx1.

Double labeling was done using an anti-ASIC1a antibody (Fig. 2) and specific markers of retinal cells. To test the specificity of anti-ASIC1a antibody within the retina, we performed Western blot experiments on ASIC1a-transfected COS cells and on rat retina extracts (Fig. 2A). In both conditions, it showed the expression of ASICla protein at $\sim 60 \mathrm{kDa}$ (predicted molecular weight, $59.6 \mathrm{kDa}$ ). A minor upper band below $80 \mathrm{kDa}$ was also detected and could correspond to the glycosylated form of ASICla (Alvarez de la Rosa et al., 2003), and a minor lower band could be attributed to a degradation form of the protein. By immunochemistry, ASICla immunoreactivity was detected in the inner segment of cone photoreceptors, in the inner nuclear layer, and in the layer that includes ganglion cells and displaced amacrine cells. Immunoreactivity was also markedly present in the inner plexiform layer (IPL) and slightly in the outer plexiform layer (Fig. 2 B). For double-labeling experiments (Fig. $2 C-G$ ), we used specific markers of the different cell types present in the retina: PNA as marker for inner and outer segments of cone photoreceptors (Hageman and Johnson, 1986), calbindin for 

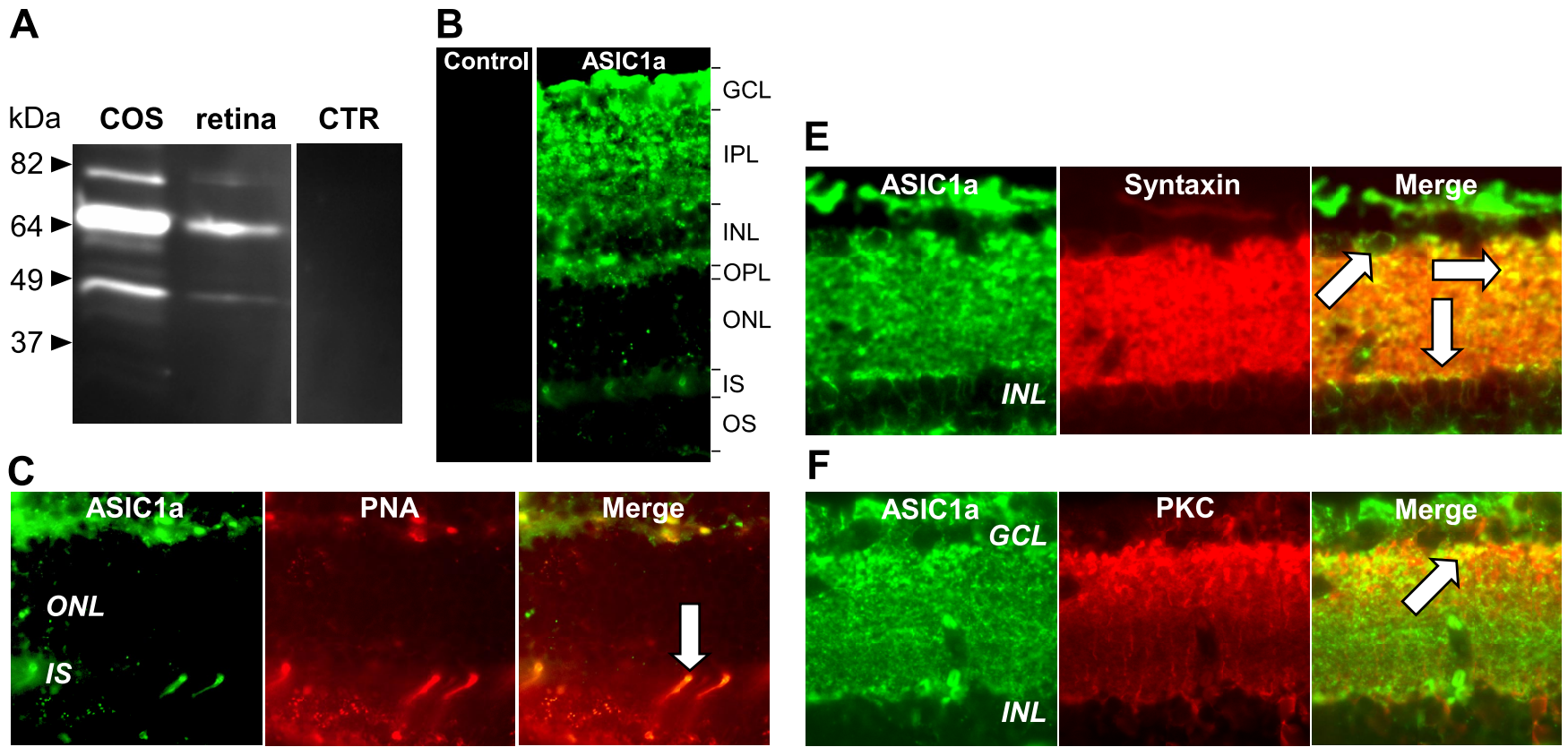

$\mathbf{F}$

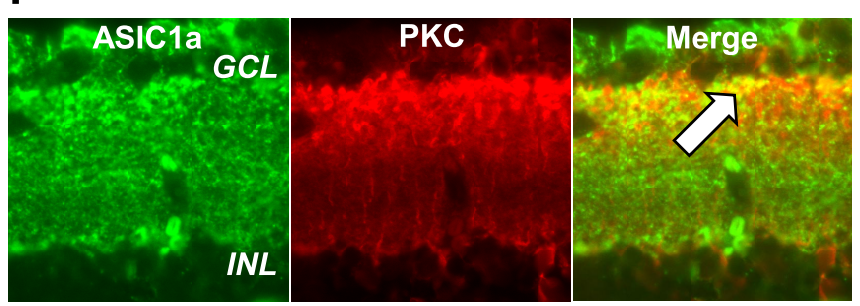

D
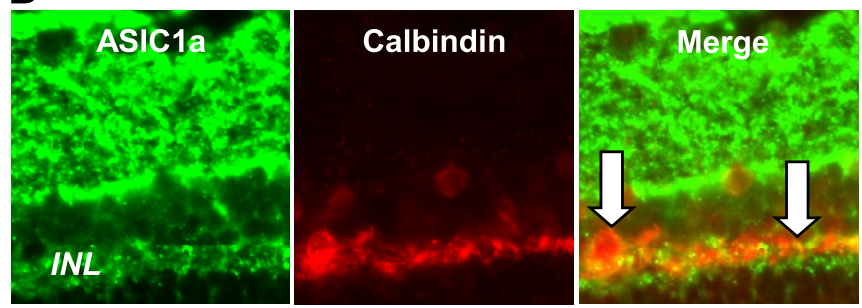

G
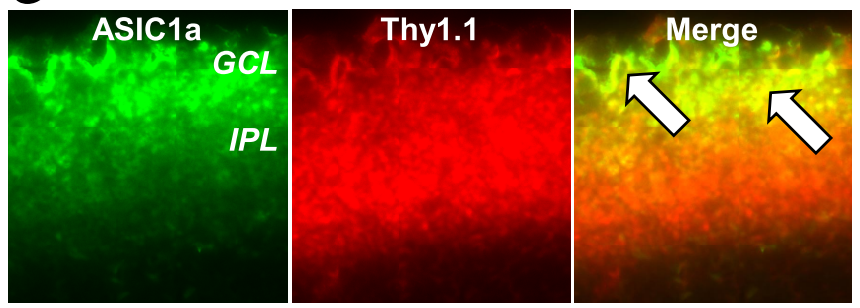

Figure 2. Immunodetection of ASIC1a in the retina. A, Western blot experiments using anti-ASIC1a antibody are shown on nontransfected (CTR) and ASIC1a-transfected (COS) COS cells, and rat retina extract (retina) the expression of ASIC1a protein at $\sim 60 \mathrm{kDa}$ (predicted molecular weight, $59.6 \mathrm{kDa}$ ). Two minor bands (below and above) were also present in the ASIC1a-expressing conditions only. $\boldsymbol{B}$, Immunolabeling rat retina with anti-ASIC1a antibodies revealed the presence of ASIC1a protein in cells and particularly at the synapse levels throughout the retina. Double labeling was done to specify the cellular types in the retina that expressed the ASIC1a protein. Arrows indicate observed signals. C, ASIC1a was colocalized within inner cone segment with PNA marker. $\boldsymbol{D}$, It was also expressed by some of the calbindin-expressing cells that correspond to horizontal cells and particularly at the synapse levels onto photoreceptors. $\boldsymbol{E}$, It was codetected with syntaxin as a marker of amacrine cells, at the membrane level (arrow pointing down), and the synapse level in the IPL (horizontal arrow), and displaced amacrine cells present in the GCL (arrow pointing up). $\boldsymbol{F}$, ASIC1a was present in bipolar cell synapses in the IPL as shown by the colocalization with PKC. G, The Thy1.1 colabeling highlighted ASIC1a expression in ganglion cells and at the synapses with second-order cells in the IPL. OPL, Outer plexiform layer; ONL, outer nuclear layer; IS, inner segments; OS, outer segments.

horizontal cells (Pasteels et al., 1990), syntaxin for amacrine cells (Barnstable et al., 1985), PKC $\alpha$ for rod bipolar cells (Greferath et al., 1990), and Thyl.1 for ganglion cells (Barnstable and Drager, 1984). Colabeling with PNA clearly confirmed the presence of ASICla in inner segments of cones as the only labeling in photoreceptors (Fig. 2C). Double labeling with anti-Thyl.1 antibody showed that the immunoreactivity appeared mainly localized in the somata of ganglion cells and their synaptic connections in the inner plexiform layer (Fig. 2G). The very dense immunostaining of the IPL corresponded to the presence of ASICla in the dendrites of amacrine cells and also in synaptic clefts of bipolar cells, because double labeling with anti-syntaxin antibody (Fig. $2 E$ ) and anti-PKC antibody (Fig. $2 F$ ) showed perfect colocalization with ASIC1a. In the INL, the immunoreactivity of ASICla was observed in cell bodies of some amacrine cells (Fig. 2E), but this immunoreactivity was absent in cell somata of bipolar cells (Fig. $2 F)$. Double labeling with an anti-calbindin D-28k antibody as specific marker of horizontal cells and their processes (Fig. 2D) demonstrated that the immunoreactivity of ASICla was present in the somata and the dendrites of these cells. Except for the horizontal cell dendrite labeling, no other immunoreactivity of ASICla antibody was observed at high magnification (i.e., ribbon synapses were not labeled).

\section{ASIC currents in ganglion cells}

Retinal primary culture cells were vitally labeled with anti-Thy 1.1 antibody, because the Thy1.1 antigen is extracellularly expressed on ganglion cell membranes, and fluorescent cells were studied by the patch-clamp technique in the whole-cell configuration (Fig. 3). Labeled cells were $\sim 17 \mu \mathrm{m}$ in diameter (17.14 \pm $1.14 \mu \mathrm{m} ; n=14)$ and were able to trigger action potentials when stimulated. These three elements clearly indicated the cells were ganglion cells. On these cells, we were able to measure an ASIC current that displayed a half-maximal activation of $\mathrm{pH} 5.24 \pm$ 0.15 (Fig. $3 A$ ), a value close to those already described for currents flowing through heteromeric ASIC2a-containing channels (Baron et al., 2001; Zhang and Canessa, 2001; Hesselager et al., 2004). Moreover, the current was potentiated $(+71.8 \pm 0.8 \%$ increase of the $\mathrm{pH}$ 6.3-induced current; $n=12$ ) by zinc (Fig. $3 B$ ), a property reported to be characteristic of an ASIC2a-containing channel (Baron et al., 2001). Finally, we showed that this native ASIC current was not sensitive to the PcTx1 (Fig. 3B), conversely to a homomeric ASIC1a, which is highly sensitive to PcTx1, a peptide extracted from tarantula venom that specifically blocks its activity (Escoubas et al., 2000). This result on ganglion cells strongly suggests that the native ASIC current is not carried by a homomeric ASICla channel. Because of the relatively rapid ki- 
A

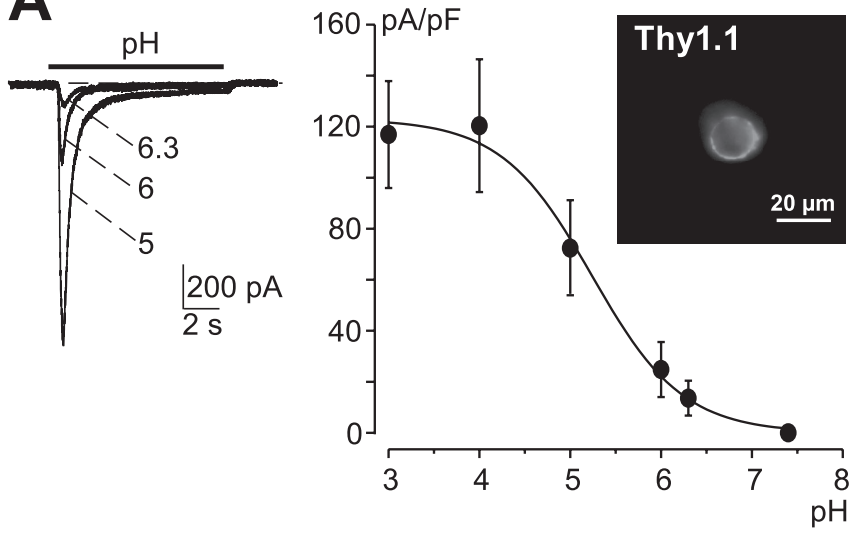

B
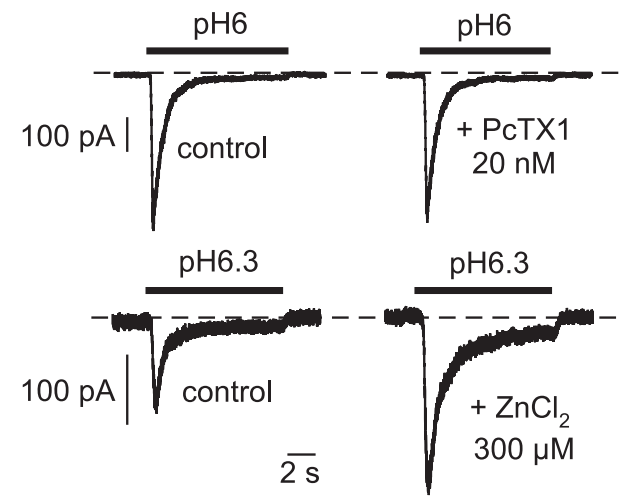

Figure 3. Native proton-activated current from cultured rat retinal ganglion cell. Cultured rat retinal ganglion cells positively labeled by anti-Thy1 antibody $(\boldsymbol{A}$, inset) were voltage clamped to a holding potential of $-50 \mathrm{mV}$, and the native ASIC current was generated by an external pH drop (as indicated by the bars above each current traces). The dotted lines represent the zero current levels. $\boldsymbol{A}$, pH-dependency relationship of the native ASIC current recorded form cultured rat retinal ganglion cells ( $n=14$ cells). $\boldsymbol{B}$, Effects of the spider toxin PcTx1 ( $20 \mathrm{~nm}$ ) and of $\mathrm{ZnCl}_{2}(300 \mu \mathrm{m})$ on the native ASIC current ( $n=10$ and 12 , respectively). Error bars represent SEM.

netics of the native current ( $\mathrm{tau}=471 \pm 49 \mathrm{~ms}$ for the inactivation rate at $\mathrm{pH} 5,-50 \mathrm{mV}$ ), it may thus be supported by a heteromeric channel formed with the three ASIC isoforms ASICla, ASIC2a, and ASIC3 (Hesselager et al., 2004), or a not yet described ASIC isoform that is sensitive to zinc. However, because of in situ experiments, we favor the first hypothesis.

\section{ASIC1a current and antisense oligonucleotide characterizations in F-11 cells}

To analyze the role of currents generated by ASIC1a-containing homomeric and heteromeric ASIC channels, we set up an antisense strategy. This was chosen instead of an ASIC1 knock-out technique for several reasons. ASIC1a comes from a gene that gives another splice variant (ASIC1b), and we wanted to discriminate between the two isoforms. Also, compensation mechanisms or morphological changes of the retina could occur during development. We thus decided to use extemporaneous knock-down. Before using them in vivo, ASICla antisense oligonucleotides were first investigated in vitro. For this purpose, we chose F-11 cells, a dorsal root ganglion-derived cell line. The reason for this choice was that we found that this cell line expressed a native ASICla homomeric channel. Figure 4 shows the properties of the acid-induced native current present on F-11 cells. It was the first characterization of ASIC activity on F-11 cells. This current had the $\mathrm{pH}$ dependence (Fig. $4 A$ ) and the inactivation time constants
(Fig. 4C) expected for an ASIC1a homomeric current (Waldmann et al., 1997a), because it opens transiently for $\mathrm{pH}$ values from 7.2 and under with a $\mathrm{pH}_{0.5}$ of 6.2 (Waldmann et al., 1997a) and responds to dynamic $\mathrm{pH}$ fluctuations. The F-11 cell current was fully inhibited by PcTx1 (Fig. 4B). In addition, RT-PCR experiments revealed that the ASICla subunit was the only ASIC subunit to be expressed in F-11 cells (Fig. 4D). The effect of antisense oligonucleotides on ASIC1a expression was characterized using transfection of F-11 cells with FITC-labeled phosphorothioate oligonucleotides and oligofectamine. Fluorescent cells were analyzed by electrophysiology to assess ASIC1a current activity. Two different oligonucleotide sequences (AS1 and AS2) were tested. Both oligonucleotides were active in knocking down ASIC1a expression (Fig. 4E,F) and had their maximal inhibitory effect $(-91.6$ and $-76.8 \%) 72 \mathrm{~h}$ after the beginning of the treatment. The AS1 sequence that gave the better level of inhibition was chosen for in vivo experiments.

\section{In vivo effects of intraocular PcTx1}

To assess the effect of PcTx1 in vivo on electrical activity of sensory retina, the peptide, which can only block homomeric ASIC1a channels, was delivered by injection via intravitreal route. Photopic Macherey-Nagel were measured. The injection of the buffer solution alone had no appreciable effect on ERGs and displayed values similar to the sham control and to the noninjected control condition. Figure $5(A, B)$ shows that, as soon as $4 \mathrm{~h}$ after intravitreal injection, PcTxl reduced significantly the photopic a-wave, b-wave, and OP amplitudes comparatively to buffer-injected conditions. At the highest intensity (i.e., $2.98 \mathrm{log}$ cd.s. $\mathrm{m}^{-2}$ ), the mean amplitudes of the a-waves, b-waves, and OPs were, respectively, $18.3 \pm 2.7,252 \pm 21$, and $125 \pm 15 \mu \mathrm{V}$ for the buffer-treated group and $6.7 \pm 1.8,184.0 \pm 12.3$, and $40 \pm 25$ $\mu \mathrm{V}$ for the PcTxl-treated group, corresponding to amplitude decreases of $\sim 68,30$, and $68 \%(n=6 ; p<0.0001,0.0004$, and 0.0001 , respectively). The ratio of the b-wave to the a-wave became higher in the PcTxl-treated group than in the control group (Fig. $5 C$ ). These results were statistically significant from an intensity of 2.21 log.cd.s.m ${ }^{-2}(p<0.05)$ and indicated that ASICla inactivation induced a retinal dysfunction at the level of cone phototransduction.

Analysis of implicit times also showed significant group effects (Fig. 5D). The implicit time of the PcTx1-treated group a-wave was slightly yet significantly increased, compared with the implicit time of the control group a-wave, from an intensity of 2.48 log.cd.s.m ${ }^{-2}(p<0.05)$. Concerning the b-wave implicit time, it was also significantly increased in the PcTx1-treated group compared with the control group from an intensity of 2.21 log.cd.s.m ${ }^{-2}(p<0.05)$. At $24 \mathrm{~h}$ after treatment, the amplitudes were still significantly affected, and after $72 \mathrm{~h}$, complete recovery was observed (Fig. 7A).

Therefore, the significant and reversible decrease of photopic ERG by PcTx1 suggests that the activation of ASIC1a current positively modulates the gain of the cone pathway.

\section{In vivo effects of antisense oligonucleotides}

Naked phosphorothioate oligonucleotides have been shown to be highly effective for experimental protein expression regulation in the retina as they penetrate the different cell layers from the ganglion cells to photoreceptors (Rakoczy et al., 1996; Rickman and Rickman, 1996; Barnett and Pow, 2000). We therefore used this technology with ASIC1a antisense oligonucleotides. The intravitreal injection of sense oligonucleotide did not induce any significant impairment of retinal function when compared with 
A
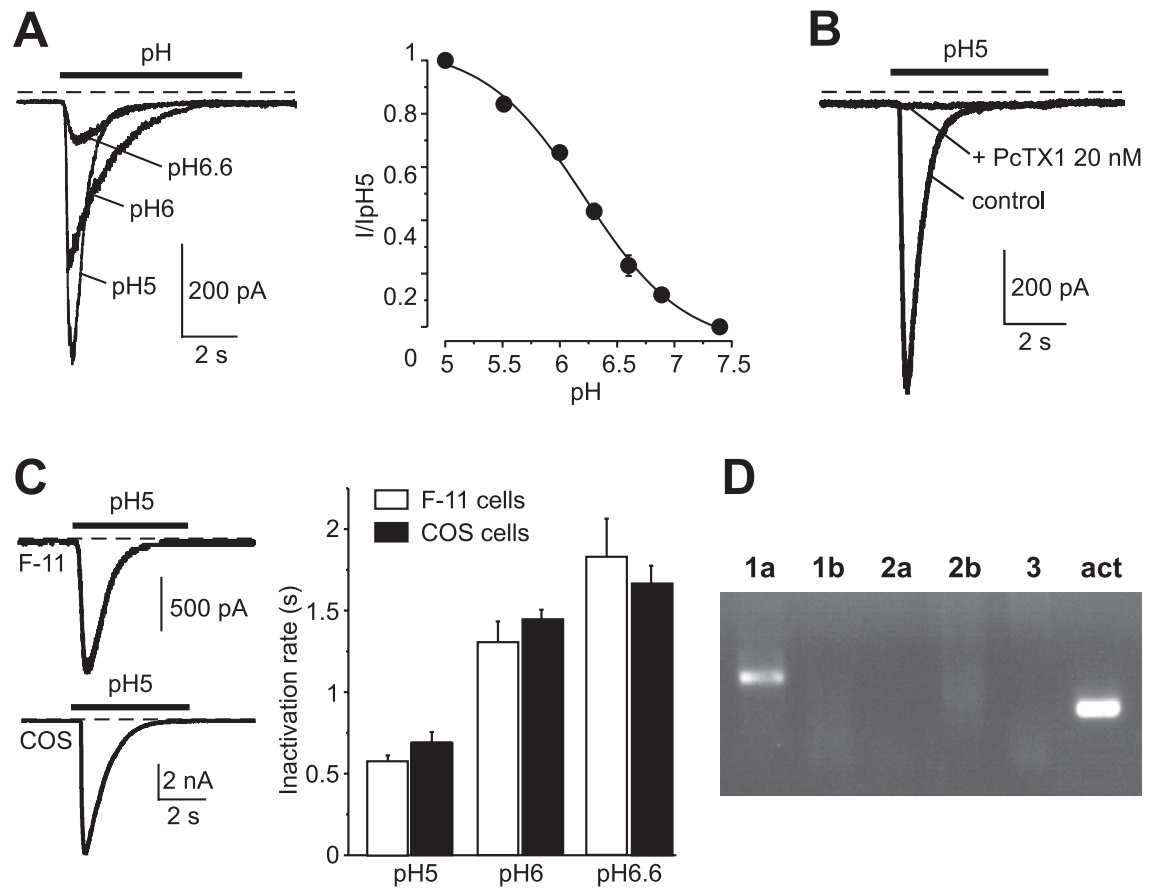

D
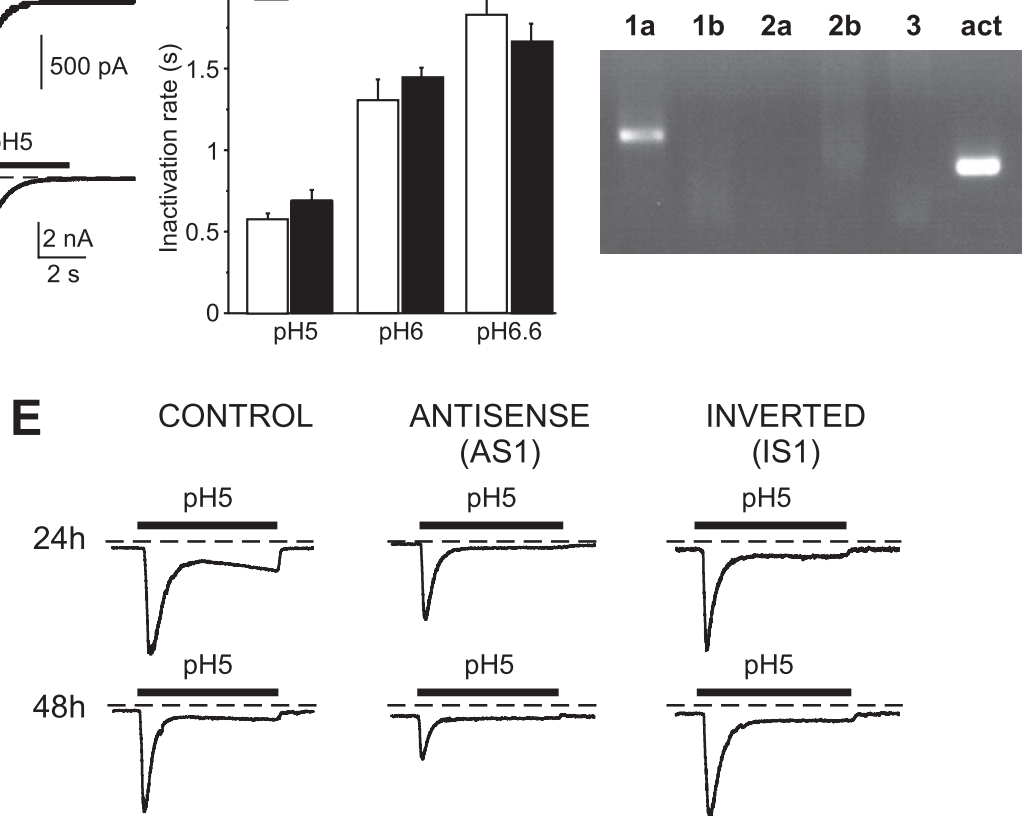

$72 \mathrm{~h}$
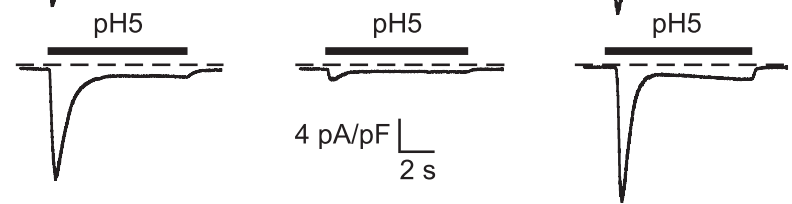

F

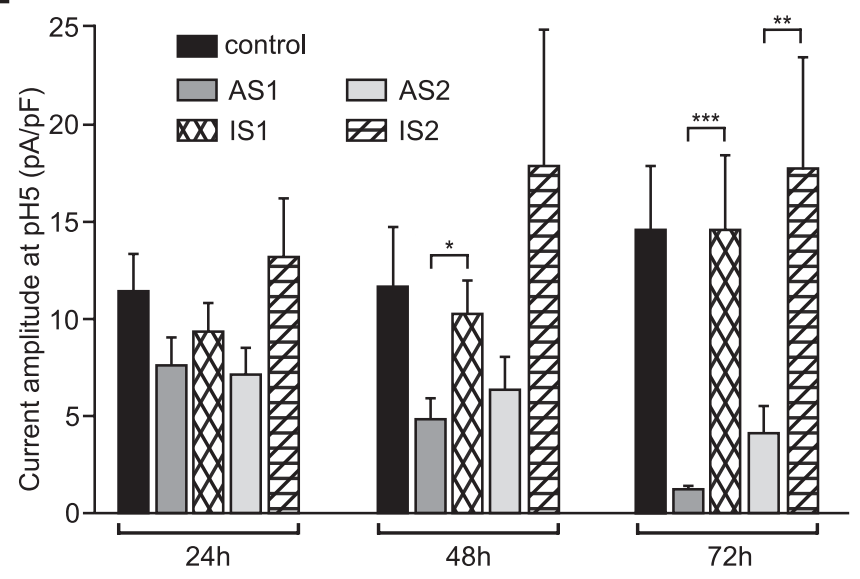

Figure 4. Characterization of ASIC1a antisense oligonucleotides using the F-11 cell line. Native proton-activated inward current was recorded from $\mathrm{F}-11$ cells using the whole-cell configuration of the patch-clamp technique at a holding potential of -50 $\mathrm{mV}$. This current was generated following a rapid decrease of the external $\mathrm{pH}$ (from $\mathrm{pH} 7.4$ to the $\mathrm{pH}$ value indicated at each current trace). The dotted lines represent the zero current level. $A$, The $\mathrm{pH}$ dependency of this native current is similar to the one of ASIC 1 a homomeric current, with a half-maximal activation $\mathrm{pH}_{0.5}=6.21 \pm 0.05$ ( $n=13$ cells). $\boldsymbol{B}$, Inhibition of the F- 11 cells protonactivated native current by $20 \mathrm{~nm}$ of the spider toxin PcTX1 ( $n=8$ cells; $p<0.01$, paired Student's $t$ test). $C$, Comparison of the proton-activated current recorded from F-11 cells to ASIC1a homomeric current recorded from transfected COS cells. The inacti- control and saline-injected groups. The means of a- and b-wave amplitudes in this condition were not significantly affected $(p>0.05)$ over a $7 \mathrm{~d}$ period after injection (Fig. 7B). The sense oligonucleotideinjected eyes were then subsequently used as controls for antisense oligonucleotideinjected eyes.

Figure 6 summarizes the effects of ASIC1a knockdown on photopic ERGs (i.e., on cone function) using antisense treatment. At day 3, the observed decrease of the photopic a- and b-wave amplitudes confirmed that the gain of cone pathway was also affected (Fig. 6A). At high intensity $\left(2.98 \mathrm{log}\right.$ cd.s. $\left.\mathrm{m}^{-2}\right)$, the mean of aand b-wave amplitude values were $19.2 \pm$ 1.7 and $247 \pm 17 \mu \mathrm{V}$ in the sense-injected group and $6.2 \pm 1.0$ and $138 \pm 13 \mu \mathrm{V}$ in the antisense-treated group, corresponding to an amplitude decrease of $\sim 69 \%$ $(n=6 ; p<0.0001)$ for the a-wave and $47 \%(n=6 ; p<0.0002)$ for the $b$-wave in the antisense-treated group. The ratio of the b-wave to the a-wave became higher in the antisense-treated group than in sensetreated group (Fig. $6 \mathrm{C}$ ). These results indicate that ASICla disruption induces a retinal dysfunction at the level of cone phtototransduction, as does the PcTx1 treatment. The peak implicit times of aand b- waves were approximately, and respectively, 4 and $10 \mathrm{~ms}$ longer in the antisense-treated group than those of the sense-treated group (Fig. 6D). These significant changes were only observed at high intensities (from an intensity of 2.48 $\log$ cd.s.m $\left.{ }^{-2} ; p<0.05\right)$. The OPs were significantly affected (Fig. 6B). The mean amplitudes were $116 \pm 15$ and $60 \pm 25 \mu \mathrm{V}$ in the sense- and antisense-injected eyes, respectively, corresponding to a decrease of $48 \%(n=6 ; p<0.0002)$. At day 5 , the amplitudes remained highly affected with decreases of $43.5,22.5$, and $34 \%(n=6$; $p<0.001,0.01$, and 0.002) for the a-wave,

\footnotetext{
$\leftarrow$

vation time constants of both currents were measured using a monoexponential fit. As shown by the histogram, the homomeric ASIC1a current (black bars) has the same inactivation rates as those of the proton-activated F-11 cells native current (white bars; $n=8-26$ ). D, RT-PCR experiments show that ASIC1a is the only ASIC subunit that is expressed in F-11 cells. $\boldsymbol{E}$, Typical pH5-evoked native ASIC1a whole-cell currents recorded at $-50 \mathrm{mV}$ from F-11 cells treated or not for 24,48 , or 72 h with the AS1 or IS1 oligonucleotides. $\boldsymbol{F}$, Statistical analysis of the native ASIC1a current amplitudes measured from F-11 cells treated with the AS1 or IS1 oligonucleotides or with the AS2 or IS2 oligonucleotides, or from control F-11 untreated cells $\left(n=10-36 ;{ }^{*} p<0.05,{ }^{* *} p<\right.$ $0.01,{ }^{* * *} p<0.001$, Kruskal-Wallis test followed by Dunns post hoc test). Error bars represent SEM.
} 
A

$\log$ cd.s. $\mathrm{m}^{-2}$
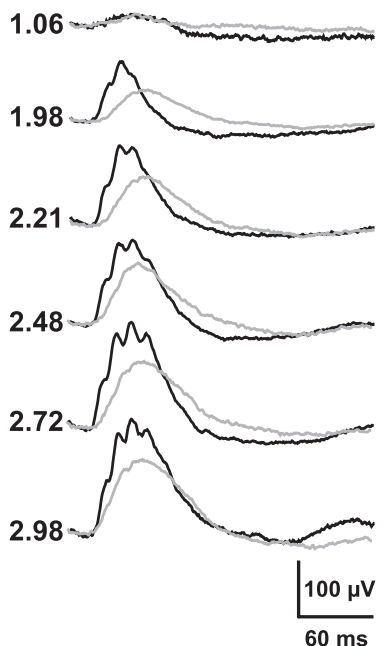

B
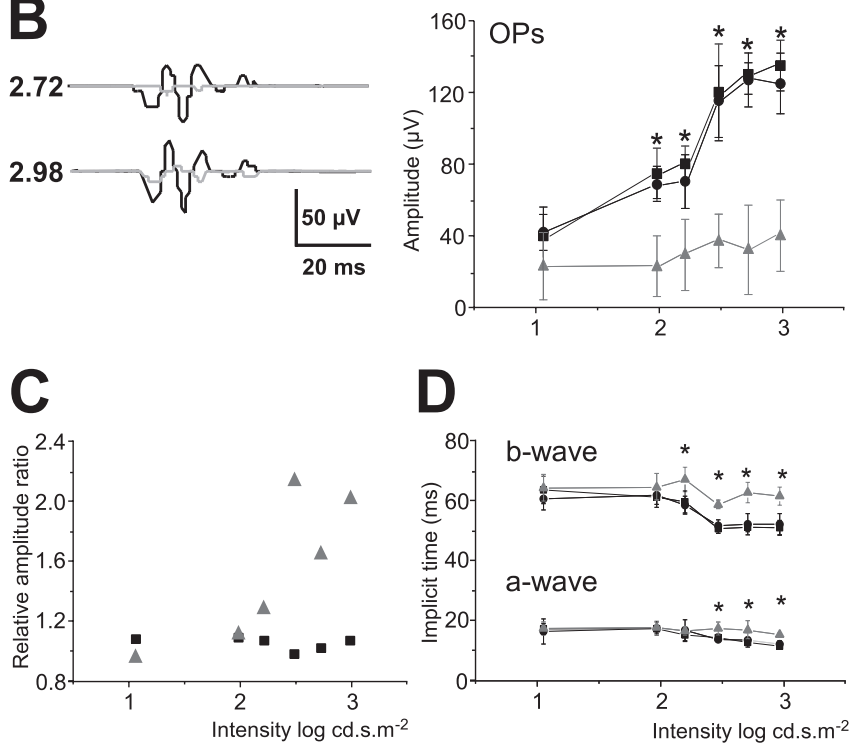

Figure 5. In vivo effects of PcTx1 on photopic ERGs. $\boldsymbol{A}$, Typical recordings $4 \mathrm{~h}$ after PcTx1 treatment, with black curves corresponding to control experiments and gray curves to PcTx 1 experiments. Values of the a-wave (top graph) and b-wave (bottom graph) amplitudes show sham control (black squares), buffer alone (black circles), and PCTx1 (gray triangles and gray line) conditions. $\boldsymbol{B}, 0$ scillatory potentials measured $4 \mathrm{~h}$ after $P c T x 1$ treatment, with black curves corresponding to sham control experiments and gray curves to PcTx1 experiments. Values are plotted as amplitude of OPs at different intensities, showing sham control, buffer alone, and PCTX1 conditions (same symbols as above). Data are expressed as mean \pm SD, and two-way ANOVA (ERG vs treatment and intensities) indicated a highly significant interaction between treatment and intensities ( $p<0.0001$ for a-wave, b-wave, and OPs, respectively). ${ }^{*} p<0.05$ (Bonferroni's post hoc test was used to evaluate amplitude difference among individual intensities). C, Ratios of b-wave amplitude to a-wave amplitude were expressed as relative ratios and plotted as function of light intensities (black squares correspond to control condition and gray triangles to PcTx1 treatment). Each point is the ratio of $n=6$ animals normalized to the ratio obtained in the control group $(n=6)$. $D, A$-wave and b-wave implicit times were measured from the flash onset to the peak of the $a$ - and $b$-wave versus flash intensities and expressed as mean \pm SD (Bonferroni's post hoc test was used to evaluate amplitude difference among individual intensities, ${ }^{*} p<0.05$ ) (same symbols as in $\boldsymbol{A}$ ).

b-wave, and OPs, respectively (Fig. 7B). The recovery was complete at day 7.

As general observations, decreases in a- and b-wave amplitudes were paralleled by increased response latencies. Moreover,
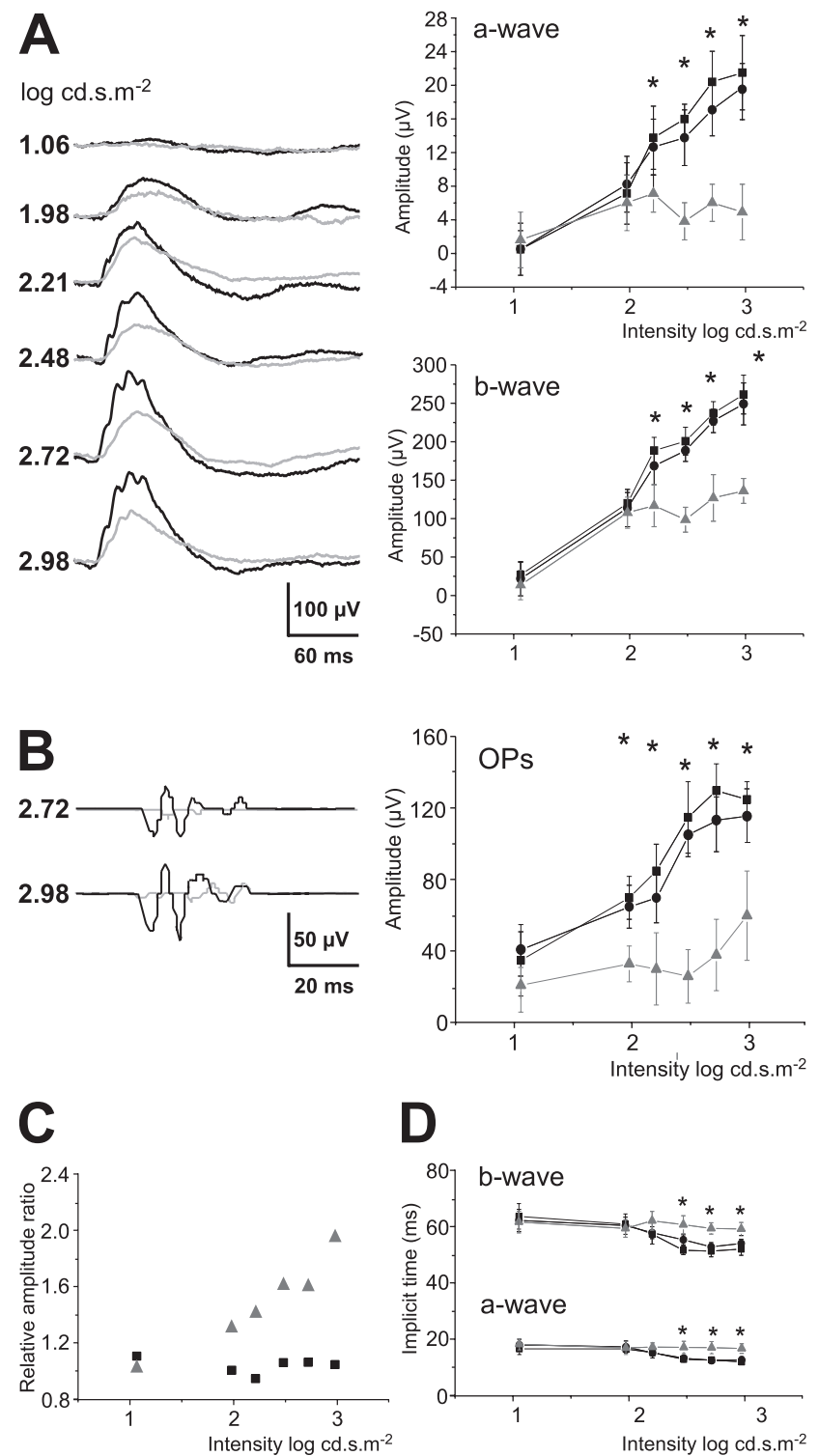

Figure 6. In vivo effects of ASIC1a antisense on photopic ERGs. A, Typical ERG recordings $3 \mathrm{~d}$ after the second oligonucleotide injection at increasing light intensities with black curves corresponding to saline experiments and gray curves to antisense experiments. Values of a-wave (top graph) and b-wave (bottom graph) amplitude are plotted according to light intensities, showing saline-injected (black squares), sense (black circles), and antisense (gray triangles and gray line) conditions. $\boldsymbol{B}$, Oscillatory potentials measured $3 \mathrm{~d}$ after antisense treatment, with black curves corresponding to saline experiments and gray curves to antisense experiments. Values are plotted as amplitude of OPs at different intensities, showing saline, sense, and antisense conditions (same symbols as above). Data are expressed as mean \pm SD, and two-way ANOVA (ERG vs treatment and intensities) indicated a highly significant interaction between treatment and intensities ( $p<0.0001$ for a-wave, b-wave, and OPs). ${ }^{*} p<0.05$ (Bonferroni's post hoc test was used to evaluate amplitude difference among individual intensities). $C$, Ratios of $b$-wave amplitude to a-wave amplitude were expressed as relative amplitude ratios and plotted as function of light intensities (black squares correspond to control condition and gray triangles to antisense treatment), and each point was the ratio of $n=6$ animals normalized to the ratio obtained in the control group $(n=6)$. $\boldsymbol{D}, \mathrm{A}$-wave and b-wave implicit times were measured from the flash onset to the peak of the $a$ - and $b$-wave versus flash intensities and expressed as mean $\pm S D$ (Bonferroni's post hoc test was used to evaluate amplitude difference among individual intensities; ${ }^{*} p<0.05$ ) (same symbols as in $\boldsymbol{A}$ ).

the decrease of a-wave, b-wave, and OP amplitudes resulting from PcTx1 and antisense treatments under scotopic conditions (data not shown) was small, although significant, and occurred only at the brightest light stimuli as results of cone contamina- 
A Photopic ERGs \pm PcTX1
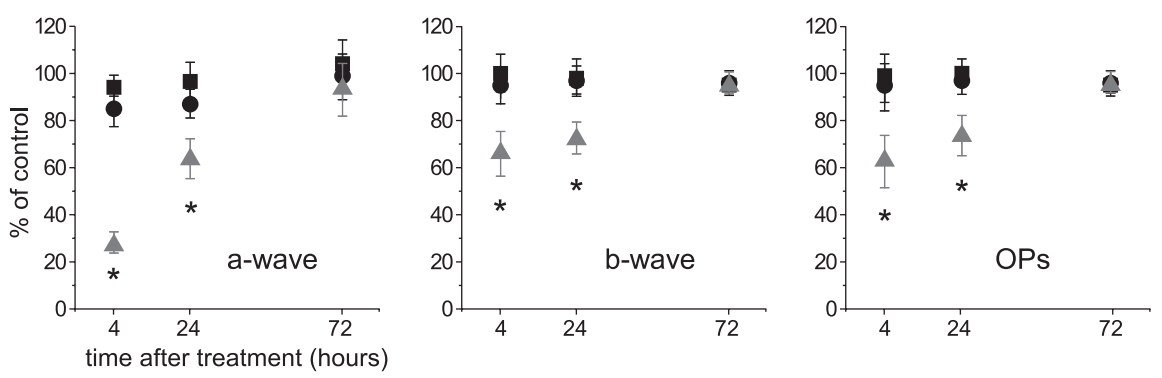

B Photopic ERGs \pm AS1
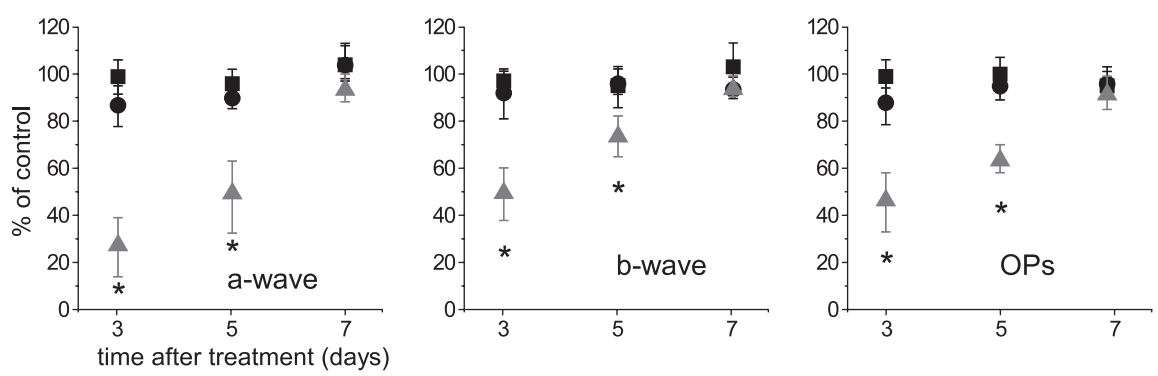

Figure 7. Time course of the in vivo effects on photopic ERGs of PcTx1 or antisense treatment. $A$, Percentage values of a-wave (left graph), b-wave (middle graph), and OP (right graph) amplitudes of the photopic ERGs plotted as percentage of the control intensity according to time elapsed from the injection time, showing sham (black squares), buffer alone (black circles), and PcTx1-injected (gray triangles) conditions. B, Percentage values of a-wave (left graph), b-wave (middle graph), and OP (right graph) amplitudes of the photopic ERGs plotted according to time elapsed from the injection time, showing saline (black squares), sense (black circles), and antisense conditions (gray triangles). Two-way ANOVA was performed (ERGs vs intensities and treatment; data not shown), and only the amplitude values of the a-wave, $b$-wave, and OPs obtained with each animal at high intensity $\left(2.98 \log c\right.$ d.s. $\left.\mathrm{m}^{-2}\right)$ were normalized to control values obtained from the control group at each time point of the study. Values represent percentages of mean \pm SD of the a-wave, $b$-wave, and OPs. ${ }^{*} p<0.05$ (Bonferroni's post hoc test was used to evaluate amplitude difference among individual intensities).

tion. Therefore, the significant and reversible decrease of ERG by antisense or PcTx1 treatment clearly suggests that the activation of ASIC1a-containing channels positively modulates the gain of the cone photoreceptor pathway.

\section{Discussion}

The retina is a complex tissue where multiple interwoven circuits transmit photon signals from the light-sensitive photoreceptors to output collecting ganglion cells. Scotopic vision (darkness and low level of light) is supported by rods, whereas photopic vision (high level of light) is supported by cones. Rod and cone signals are transmitted to bipolar cells that relay these signals to ganglion cells. Horizontal cells act as crosstalk circuits between photoreceptors; amacrine cells act as crosstalk circuit between bipolar cells and ganglion cells. $\mathrm{pH}$ fluctuations that locally occur during light intensity variations have a significant impact on retinal cell behavior. The expression of ASICla exclusively in the inner segment of cones at the photoreceptor level, and also in the INL, IPL, and ganglion cell layer (GCL) allowed us to investigate the role of the acid-sensing ion channel ASICla in retinal function, and particularly in cone phototransduction and signal transmission modulation. For this study, retina function was analyzed by ERG measurements to determine whether inactivation of ASIC1a expression and function in vivo triggered retinal defects and to gain insight into the role of ASICla in retinal physiology. This was done either by treatment with the peptide PcTx1, a specific blocker of homomeric ASIC1a, or with antisense oligonucleotides to prevent the expression of the ASIC1a isoform, and there- fore its participation in both homomeric and heteromeric ASICla-containing channels. Both PcTx1- and antisensetreated groups had: (1) attenuated ERG aand b-wave amplitudes, (2) significantly longer $\mathrm{a}$ - and b-wave implicit times, and (3) larger ratios of b-wave to a-wave than respective controls. Together, these results indicated that cones had then subnormal photoreceptor function.

Indeed, when ASIC1a activity was suppressed, the early response of cones to light was decreased as seen by smaller a-wave amplitude. As reported previously, the local fluctuations of energy consumption, acid production, and extrusion between light and dark might be one mechanism that could create transient, localized $\mathrm{pH}$ changes around photoreceptors after light exposure that can act on ASIC channels (Ettaiche et al., 2004). In cone cells, light activates visual pigments that trigger the transducin cascade leading to cGMP hydrolysis. This drop in cGMP provokes the closure of the cGMP-gated cation channels resulting in a hyperpolarization of the photoreceptor represented by the a-wave of the ERG. Therefore, the a-wave represents the collapse of darkcirculating current between inner and outer segments of cones. In contrast, light generates changes in the cytoplasmic concentration of $\mathrm{Ca}^{2+}$ in the outer segment that are far larger and faster in cones than in rods (Miller et al., 1994). This distinction reflects $\mathrm{rod} /$ cone differences in the elements controlling $\mathrm{Ca}^{2+}$ homeostasis. ASICla is permeable to $\mathrm{Ca}^{2+}$, and in the presence of physiological concentrations of cations, it constitutes a nonvoltage-gated pathway for significant increase in intracellular calcium concentration (Yermolaieva et al., 2004). Its intrinsic depolarizing effect is very quick compared with intracellular $\mathrm{Ca}^{2+}$ changes it induces (Yermolaieva et al., 2004). The inactivation by PcTx1 or antisense treatment of the ASICla present in the inner segments of cones can induce, under bright light stimulus, a decrease in cytosolic $\mathrm{Ca}^{2+}$ that in turn transiently and indirectly increases the production of cGMP by guanylate cyclase. This event leads rapidly to reduce the closure of the cGMP-gated cation channel. This possible mechanism may explain the reduction of the a-wave amplitude in PcTx1- and antisense-treated groups.

We can propose that ASICla could have a significant action in an early process of signal transduction. By influencing the calcium entry in cones, ASIC1a could thus contribute to the amplitude of the cone response and its adaptation to light.

ASIC1a was also detected in the inner nuclear layer and GCL and particularly at the synapses along the signal transmission pathway (from cone photoreceptors to ganglion cells) and those in the feedback loops (horizontal cells and amacrine cells). The suppression of its activity decreased the photopic b-wave amplitude and oscillatory potentials. The photopic b-wave is the summation of the responses of both the ON and OFF pathways. The peak of the photopic b-wave likely originates from calcium action potential in retinal bipolar cells and is dependent on the ampli- 
tude of the a-wave. The absence of ASIC1a-containing channels in ribbon synapses suggested that the reduction of b-wave amplitude could simply be a consequence of the reduction observed in the cone a-wave.

Oscillatory potentials reflect the activity of amacrine cells (i.e., the feedback circuits between amacrine cells and bipolar cells and between ganglion cells and amacrine cells) (for review, see Wachtmeister, 1998) and represent the saturated activity of some high-amplification postreceptoral pathway (Friedburg et al., 2004). This suggests that the reduction of the OPs may be attributable to the reduction of the cone a-wave. However, in synapses, neurotransmitter release is accompanied by an acidification of the cleft pH down to pH 6.4 (Krishtal et al., 1987; Miesenbock et al., 1998; Palmer et al., 2003), and protons have been considered as important modulators of retinal signal transmission (Barnes et al., 1993; DeVries, 2001; Hirasawa and Kaneko, 2003; Palmer et al., 2003; Vessey et al., 2005). Moreover, recent studies suggest that light may induce transient acidification in conventional synapses (Palmer et al., 2003). Thus, the reduction of the OPs observed either in the presence of PcTx1 or antisense oligonucleotides could be attributable to the blocking of the ASIC1a current induced by transient light-evoked acidification in the synapses either between on-center bipolar cells and amacrine and/or ganglion cells when glutamate-containing vesicles are released or between amacrine cells and bipolar cells and/or ganglion cells when GABA-containing vesicles are released. Indeed, ASICla has been shown to take part in synaptic activity and plasticity (Wemmie et al., 2002, 2003). ASIC1a can thus participate in the facilitation of synaptic transmission of the light-induced signal and take part in the modulation of feedback activities of horizontal and amacrine cells.

We reported previously that the inactivation of the ASIC2 gene in the mouse increased the response to light of the retina (Ettaiche et al., 2004) and sensitized the retina toward lightinduced degeneration. These results suggest that ASIC2 is a negative modulator of rod phototransduction. Conversely, the alteration of the photopic ERG after inactivation of ASIC1a shown in the present study suggests that ASIC1a is a positive modulator of cone phototransduction and adaptation. Thus, the modulation of retina electrical activity in the inner nuclear layer seems to involve ASIC2 under dim light and ASIC1a in high light conditions. The strong effect of ASICla silencing on cone a-wave and oscillatory potentials might suggest a possible involvement of this ion channel in the onset of retinal pathology.

This study shows that ASIC1a is implicated in cone transduction pathway in bright light conditions. Along with ASIC2 (Brockway et al., 2002; Ettaiche et al., 2004), they are not the only isoforms present in the retina (Brockway et al., 2002; Ettaiche et al., 2004). Therefore, additional studies will be necessary to evaluate the fine localization and the window of expression of the other members of the ASIC family in the retina and to evaluate their physiological significance and their precise molecular mechanism in the vision process.

\section{References}

Akopian AN, Chen CC, Ding Y, Cesare P, Wood JN (2000) A new member of the acid-sensing ion channel family. NeuroReport 11:2217-2222.

Alvarez de la Rosa D, Krueger SR, Kolar A, Shao D, Fitzsimonds RM, Canessa CM (2003) Distribution, subcellular localization and ontogeny of ASIC1 in the mammalian central nervous system. J Physiol (Lond) 546:77-87.

Ayoub GS, Korenbrot JI, Copenhagen DR (1989) Release of endogenous glutamate from isolated cone photoreceptors of the lizard. Neurosci Res Suppl 10:S47-S55.
Barnes S, Merchant V, Mahmud F (1993) Modulation of transmission gain by protons at the photoreceptor output synapse. Proc Natl Acad Sci USA 90:10081-10085.

Barnett NL, Pow DV (2000) Antisense knockdown of GLAST, a glial glutamate transporter, compromises retinal function. Invest Ophthalmol Vis Sci 41:585-591.

Barnstable CJ, Drager UC (1984) Thy-1 antigen: a ganglion cell specific marker in rodent retina. Neuroscience 11:847-855.

Barnstable CJ, Hofstein R, Akagawa K (1985) A marker of early amacrine cell development in rat retina. Brain Res 352:286-290.

Baron A, Schaefer L, Lingueglia E, Champigny G, Lazdunski M (2001) Zn ${ }^{2+}$ and $\mathrm{H}^{+}$are coactivators of acid-sensing ion channels. J Biol Chem 276:35361-35367.

Borgula GA, Karwoski CJ, Steinberg RH (1989) Light-evoked changes in extracellular $\mathrm{pH}$ in frog retina. Vision Res 29:1069-1077.

Brockway LM, Zhou ZH, Bubien JK, Jovov B, Benos DJ, Keyser KT, Rakoczy PE, Lai MC, Watson M, Seydel U, Constable I (2002) Rabbit retinal neurons and glia express a variety of ENaC/DEG subunits. Am J Physiol Cell Physiol 283:C126-C134.

Chen CC, England S, Akopian AN, Wood JN (1998) A sensory neuronspecific, proton-gated ion channel. Proc Natl Acad Sci USA 95:10240-10245.

Copenhagen DR, Jahr CE (1989) Release of endogenous excitatory amino acids from turtle photoreceptors. Nature 341:536-539.

DeVries SH (2001) Exocytosed protons feedback to suppress the $\mathrm{Ca}^{2+}$ current in mammalian cone photoreceptors. Neuron 32:1107-1117.

Dmitriev AV, Mangel SC (2001) Circadian clock regulation of $\mathrm{pH}$ in the rabbit retina. J Neurosci 21:2897-2902.

Donner K, Hemila S, Kalamkarov G, Koskelainen A, Shevchenko T (1990) Rod phototransduction modulated by bicarbonate in the frog retina: roles of carbonic anhydrase and bicarbonate exchange. J Physiol (Lond) 426:297-316.

Escoubas P, De Weille JR, Lecoq A, Diochot S, Waldmann R, Champigny G, Moinier D, Menez A, Lazdunski M (2000) Isolation of a tarantula toxin specific for a class of proton-gated $\mathrm{Na}^{+}$channels. J Biol Chem 275:25116-25121.

Escoubas P, Bernard C, Lambeau G, Lazdunski M, Darbon H (2003) Recombinant production and solution structure of PcTx1, the specific peptide inhibitor of ASICla proton-gated cation channels. Protein Sci 12:1332-1343.

Ettaiche M, Guy N, Hofman P, Lazdunski M, Waldmann R (2004) Acidsensing ion channel 2 is important for retinal function and protects against light-induced retinal degeneration. J Neurosci 24:1005-1012.

Francel PC, Harris K, Smith M, Fishman MC, Dawson G, Miller RJ (1987) Neurochemical characteristics of a novel dorsal root ganglion $\mathrm{X}$ neuroblastoma hybrid cell line, F-11. J Neurochem 48:1624-1631.

Friedburg C, Allen CP, Mason PJ, Lamb TD (2004) Contribution of cone photoreceptors and post-receptoral mechanisms to the human photopic electroretinogram. J Physiol (Lond) 556:819-834.

Garcia-Anoveros J, Derfler B, Neville-Golden J, Hyman BT, Corey DP (1997) $\mathrm{BNaCl}$ and $\mathrm{BNaC} 2$ constitute a new family of human neuronal sodium channels related to degenerins and epithelial sodium channels. Proc Natl Acad Sci USA 94:1459-1464.

Goto Y, Peachey NS, Ripps H, Naash MI (1995) Functional abnormalities in transgenic mice expressing a mutant rhodopsin gene. Invest Ophthalmol Vis Sci 36:62-71.

Greferath U, Grunert U, Wassle H (1990) Rod bipolar cells in the mammalian retina show protein kinase C-like immunoreactivity. J Comp Neurol 301:433-442.

Grunder S, Geisler HS, Rainier S, Fink JK (2001) Acid-sensing ion channel (ASIC) 4 gene: physical mapping, genomic organisation, and evaluation as a candidate for paroxysmal dystonia. Eur J Hum Genet 9:672-676.

Hageman GS, Johnson LV (1986) Biochemical characterization of the major peanut-agglutinin-binding glycoproteins in vertebrate retinae. J Comp Neurol 249:499-510.

Hamill OP, Marty A, Neher E, Sakmann B, Sigworth FJ (1981) Improved patch-clamp techniques for high-resolution current recording from cells and cell-free membrane patches. Pflügers Arch 391:85-100.

Hesselager M, Timmermann DB, Ahring PK (2004) pH dependency and desensitization kinetics of heterologously expressed combinations of acid-sensing ion channel subunits. J Biol Chem 279:11006-11015.

Hirasawa H, Kaneko A (2003) pH changes in the invaginating synaptic cleft 
mediate feedback from horizontal cells to cone photoreceptors by modulating $\mathrm{Ca}^{2+}$ channels. J Gen Physiol 122:657-671.

Iijima T, Ciani S, Hagiwara S (1986) Effects of the external pH on Ca channels: experimental studies and theoretical considerations using a two-site, two-ion model. Proc Natl Acad Sci USA 83:654-658.

Krishtal O (2003) The ASICs: signaling molecules? Modulators? Trends Neurosci 26:477-483.

Krishtal OA, Osipchuk YV, Shelest TN, Smirnoff SV (1987) Rapid extracellular $\mathrm{pH}$ transients related to synaptic transmission in rat hippocampal slices. Brain Res 436:352-356.

Lilley S, LeTissier P, Robbins J (2004) The discovery and characterization of a proton-gated sodium current in rat retinal ganglion cells. J Neurosci 24:1013-1022.

Lingueglia E, de Weille JR, Bassilana F, Heurteaux C, Sakai H, Waldmann R, Lazdunski M (1997) A modulatory subunit of acid sensing ion channels in brain and dorsal root ganglion cells. J Biol Chem 272:29778-29783.

Mamet J, Baron A, Lazdunski M, Voilley N (2002) Proinflammatory mediators, stimulators of sensory neuron excitability via the expression of acid-sensing ion channels. J Neurosci 22:10662-10670.

Mamet J, Lazdunski M, Voilley N (2003) How nerve growth factor drives physiological and inflammatory expressions of acid-sensing ion channel 3 in sensory neurons. J Biol Chem 278:48907-48913.

Miesenbock G, De Angelis DA, Rothman JE (1998) Visualizing secretion and synaptic transmission with $\mathrm{pH}$-sensitive green fluorescent proteins. Nature 394:192-195.

Miller JL, Picones A, Korenbrot JI (1994) Differences in transduction between rod and cone photoreceptors: an exploration of the role of calcium homeostasis. Curr Opin Neurobiol 4:488-495.

Newman EA (1996) Acid efflux from retinal glial cells generated by sodium bicarbonate cotransport. J Neurosci 16:159-168.

Oakley Jr B, Wen R (1989) Extracellular pH in the isolated retina of the toad in darkness and during illumination. J Physiol (Lond) 419:353-378.

Palmer MJ, Hull C, Vigh J, von Gersdorff H (2003) Synaptic cleft acidification and modulation of short-term depression by exocytosed protons in retinal bipolar cells. J Neurosci 23:11332-11341.

Pasteels B, Rogers J, Blachier F, Pochet R (1990) Calbindin and calretinin localization in retina from different species. Vis Neurosci 5:1-16.

Pasternack M, Smirnov S, Kaila K (1996) Proton modulation of functionally distinct GABAA receptors in acutely isolated pyramidal neurons of rat hippocampus. Neuropharmacology 35:1279-1288.

Peachey NS, Goto Y, al-Ubaidi MR, Naash MI (1993) Properties of the mouse cone-mediated electroretinogram during light adaptation. Neurosci Lett 162:9-11.

Peachey NS, Goto Y, Quiambao AB, al-Ubaidi MR (1995) Functional consequences of oncogene-induced photoreceptor degeneration in transgenic mice. Vis Neurosci 12:513-522.

Platika D, Boulos MH, Baizer L, Fishman MC (1985) Neuronal traits of clonal cell lines derived by fusion of dorsal root ganglia neurons with neuroblastoma cells. Proc Natl Acad Sci USA 82:3499-3503.

Rakoczy PE, Lai MC, Watson M, Seydel U, Constable I, Yamamoto F, Steinberg RH, Borgula GA (1996) Targeted delivery of an antisense oligonucleotide in the retina: uptake, distribution, stability and effect. Antisense Nucleic Acid Drug Dev 6:207-213.

Rickman DW, Rickman CB (1996) Suppression of trkB expression by antisense oligonucleotides alters a neuronal phenotype in the rod pathway of the developing rat retina. Proc Natl Acad Sci USA 93:12564-12569.

Salinas M, Rash LD, Baron A, Lambeau G, Escoubas P, Lazdunski M (2005) Binding site and mechanism of action of the spider toxin PcTxl on the proton-gated cation channel ASIC1a. J Physiol (Lond) 570:339-354.

Tang CM, Dichter M, Morad M (1990) Modulation of the N-methyl-Daspartate channel by extracellular $\mathrm{H}^{+}$. Proc Natl Acad Sci USA 87:6445-6449.
Toulmé J-J, Cazenave C, Moreau S (1997) Selecting, preparing, and handling antisense oligodeoxyribonucleotides. In: Antisense technology, a practical approach (Lichtenstein C, Nellen W, eds), pp 39-74. Oxford: IRL.

Traynelis SF, Cull-Candy SG (1990) Proton inhibition of N-methyl-Daspartate receptors in cerebellar neurons. Nature 345:347-350.

Vessey JP, Stratis AK, Daniels BA, Da Silva N, Jonz MG, Lalonde MR, Baldridge WH, Barnes S (2005) Proton-mediated feedback inhibition of presynaptic calcium channels at the cone photoreceptor synapse. J Neurosci 25:4108-4117.

Voilley N (2004) Acid-sensing ion channels (ASICs): new targets for the analgesic effects of non-steroid anti-inflammatory drugs (NSAIDs). Curr Drug Targets Inflamm Allergy 3:71-79.

Voilley N, de Weille J, Mamet J, Lazdunski M (2001) Nonsteroid antiinflammatory drugs inhibit both the activity and the inflammationinduced expression of acid-sensing ion channels in nociceptors. J Neurosci 21:8026-8033.

Vyklicky Jr L, Vlachova V, Krusek J (1990) The effect of external pH changes on responses to excitatory amino acids in mouse hippocampal neurones. J Physiol (Lond) 430:497-517.

Wachtmeister L (1998) Oscillatory potentials in the retina: what do they reveal. Prog Retin Eye Res 17:485-521.

Waldmann R, Champigny G, Voilley N, Lauritzen I, Lazdunski M (1996) The mammalian degenerin MDEG, an amiloride-sensitive cation channel activated by mutations causing neurodegeneration in Caenorhabditis elegans. J Biol Chem 271:10433-10436.

Waldmann R, Champigny G, Bassilana F, Heurteaux C, Lazdunski M (1997a) A proton-gated cation channel involved in acid-sensing. Nature 386:173-177.

Waldmann R, Bassilana F, de Weille J, Champigny G, Heurteaux C, Lazdunski M (1997b) Molecular cloning of a non-inactivating proton-gated $\mathrm{Na}^{+}$channel specific for sensory neurons. J Biol Chem 272:20975-20978.

Waldmann R, Champigny G, Lingueglia E, De Weille JR, Heurteaux C, Lazdunski M (1999) $\mathrm{H}(+)$-gated cation channels. Ann NY Acad Sci 868:67-76.

Wegelius K, Reeben M, Rivera C, Kaila K, Saarma M, Pasternack M (1996) The rho 1 GABA receptor cloned from rat retina is down-modulated by protons. NeuroReport 7:2005-2009.

Wemmie JA, Askwith CC, Lamani E, Cassell MD, Freeman Jr JH, Welsh MJ (2003) Acid-sensing ion channel 1 is localized in brain regions with high synaptic density and contributes to fear conditioning. J Neurosci 23:5496-5502.

Wemmie JA, Chen J, Askwith CC, Hruska-Hageman AM, Price MP, Nolan BC, Yoder PG, Lamani E, Hoshi T, Freeman Jr JH, Welsh MJ (2002) The acid-activated ion channel ASIC contributes to synaptic plasticity, learning, and memory. Neuron 34:463-477.

Winkler BS (1981) Glycolytic and oxidative metabolism in relation to retinal function. J Gen Physiol 77:667-692.

Yamamoto F, Borgula GA, Steinberg RH (1992) Effects of light and darkness on $\mathrm{pH}$ outside rod photoreceptors in the cat retina. Exp Eye Res 54:685-697.

Yermolaieva O, Leonard AS, Schnizler MK, Abboud FM, Welsh MJ (2004) Extracellular acidosis increases neuronal cell calcium by activating acidsensing ion channel 1a. Proc Natl Acad Sci USA 101:6752-6757.

Zadunaisky JA, Kinne-Saffran E, Kinne R (1989) A Na/H exchange mechanism in apical membrane vesicles of the retinal pigment epithelium. Invest Ophthalmol Vis Sci 30:2332-2340.

Zhang P, Canessa CM (2001) Single-channel properties of recombinant acid-sensitive ion channels formed by the subunits ASIC2 and ASIC3 from dorsal root ganglion neurons expressed in Xenopus oocytes. J Gen Physiol 117:563-572. 